\title{
A Problem in South African Geology.
}

THE Vredefort Mountain Land lies to the west of Vereeniging and some eighteen miles southsouth-west of Johannesburg; it is cut through by the Vaal River, which forms the boundary between the Transvaal and the Orange River Free State. Its striking topography, in marked contrast to the monotonously flat country of the northern Orange River Free State, is determined by an enormous circular boss of granite with some gneiss and schists, about twenty-seven miles in diameter. This granite boss is surrounded by a belt of sediments ranging from the Lower Witwatersrand beds (nearest to the granite) up to the Pretoria beds--in all some I3,000 feet of total thickness. Although in apparently conformable succession, the beds dip towards the granite instead of away from it, as they should do if the succession were normal; so that there is here an inversion of the strata on a very large scale. Near the granite the sediments are highly metamorphosed, the shales and slates being charged with contact minerals. These phenomena constitute a fascinating problem, which has exercised the minds of South African geologists since the earliest days of the Rand.

The granite (a quartz-orthoclase-oligoclase-biotite rock is generally accepted as identical with the old granite occurring north of Johannesburg and near Heidelberg, and as older than the Witwatersrand beds. It cannot therefore be intrusive in them, and the problem requiring solution is: What brought about the tilting and inversion of the sediments encircling the granite? And what is the cause of the contact-metamorphism shown by them ?

The memoir under review ${ }^{1}$ embodies the work done by Dr. Molengraaf, professor of geology in the Technical High School, Delft, and Dr. Hall, assistant director of the Geological Survey of the Union of South Africa, to elucidate this problem. The authors first review the various theories put forward in papers by Gibson, Molengraaf, Draper, Bunkell, Hatch, Sawyer, Jorissen, Kynaston, Mellor, and Penny, and then, after a detailed geological and petrographical description of the rocks and their tectonic history, they state their conclusions, which may be briefly summarised as follows :

(I) The granite is older than, and therefore nonintrusive into, the sediments.

(2) The over-tilting of the sediments is due to the up-doming of the central granite, which, it is suggésted, was initiated by centripetal pressure. The relief of load resulting from this movement caused a

1 "The Vredefort Mountain I.and in the Southern Transvaal and the Northern Orange Free State." By Dr. A. L. Hall and Prof. Dr. G. A. F. Molengraaff. Shaler Memurial Series. (Verhandelingen der Koninklijke Akademie van Wetenschappen te Amsterdam (Tweede sectie), Deel 24, No. 3.) Pp. xiv $+183+39$ plates. (Amsterdam: Koninklijke Akademie van Wetenschappen, 1925.) n.p. younger magma below the granite to become active and to rise, thus assisting the upward movement of the heated but passive granite.

(3) This up-doming called into play exceptionally powerful pressure which manifested itself both in the metamorphism of the encircling sediments and in the production, by compression, trituration, and local fusion, of a flinty crush-rock (pseudo-tachylyte) which occurs in countless veins both in the granite and in the encircling sediments.

(4) In the contact-belt are dykes of enstatitegranophyre, which contain numerous xenoliths of crushed quartzite derived from the Lower Witwatersrand beds. It is suggested that this apparently igneous rock is a flinty crush-rock originating from ultra-trituration and partial fusion of the sediments.

(5) The metamorphism of the sediments was, in part, regional and due to static pressure, accompanied by heat, and, in part, local and due to the emplacement of a large younger intrusion.

(6) The regional metamorphism is characterised by the production of hornblende-granulite and garnetamphibole-hornfels; the local metamorphism, by cordierite-biotite-hornfels and andalusite-biotitehornfels. Where the two are concurrent the reinforced metamorphism is indicated by the increased size and abundance of the contact-minerals.

(7) The younger intrusion, referred to in (5), is, to a great extent, concealed, although exposed as three small bosses of alkali-granite (soda-granite) and accompanying nepheline-syenite dykes. Certain gabbroic marginal intrusions in the older granite and the nearest belt of sediments are regarded by the authors as the earliest basic differentiates of the younger magma.

(8) The extension of the nepheline-syenite dykes northward across the Magaliesberg into the Pilandsberg (also a region of alkali-rocks) indicates the existence of channels of communication between the two centres of alkali-rocks and some community of origin with the Bushveld complex.

The Vredefort Mountain Land has, according to the authors, remarkable analogies with the Black Hills dome in Dakota and the Ries Kessel in Bavaria. In the Vredefort area the up-doming movement originated at a greater depth than in the Black Hills dome; and this explains why the regional and contact metamorphism are so much more developed in the Vredefort area. Stress phenomena are much in evidence both in the Vredefort and the Ries domes: but in the former they attain a marvellous development, culminating in the genesis of flinty crush-rocks on a gigantic scale. In all three cases the observed facts lead to the surmise that a hidden mass of igneous magma must be present below the central core of granite.
F. H. Hatch.

\section{Sunspots and Terrestrial Magnetism. ${ }^{1}$}

FOR a long time it has been known that sunspot frequencies have had their counterpart on the earth in the disturbances exhibited by the magnetic elements on its surface. As the sunspot period is at least eleven years, and as the variations in sunspot phenomena in successive eleven-year periods are

2 Air Ministry, Meteorological Office, London. (I) Geophysical Memoirs, No. 29. The Absolute Daily Range of Magnetic Declination at Kew Observatory, Richmond, rgor-19ro, by J. M. Stagg. 3s. net. (2) Geophysical Memoirs, No. 3o. Comparison of Magnetic Standards at British Observatories, with a Discussion of Various Instrumental Questions involved, by Dr. C. Chree. Is. $6 d$. net. (Published by the Authority of the Meteorological Committee.) H.M. Stationery Office, London. considerable, it follows that to get a comparison of normal means free from accidental effects, a large number of periods must be taken. The Kew magnetographs have been in almost continuous operation since I 858 , and the connexion between sunspots and the absolute daily range of declination (the element most easily measured), for the first 42 years of their progress up to I 900 has already been discussed. The first of the memoirs under notice treats of the same phenomena and adds another ro years to the comparison ( $\mathrm{r}$ ). The decade which is under discussion proved generally to be one of small magnetic disturbance and low sunspotted-

NO. 295I, VOL. II 7] 